\title{
EDUKASI TEPAT GUNA KOMPOSER SEBAGAI PENINGKATAN NILAI JUAL SAMPAH ORGANIK GUNA MENINGKATKAN PENDAPATAN MASYARAKAT
}

\author{
Kartika Rose Rachmadi*, Dea Aida Salsabila \\ Fakultas Ekonomi dan Bisnis, Universitas Islam Malang \\ *korespondensi email: tikarose@unisma.ac.id
}

\begin{abstract}
ABSTRAK
Sampah adalah sesuatu hasil sisa kegiatan manusia baik berupa kegiatan industri maupun domestik. Sampah merupakan problematika masyarakat Indonesia sejak lama. Sampah menumpuk dan berserakan menjadi hal biasa. Bahkan sampai mencemari lingkungan yang ada disekitarnya. Sampah dianggap hal yang kotor dan tidak memiliki nilai karena merupakan hasil sisa kegiatan manusia. Pengelolaan sampah di Indonesia kurang maksimal karena kurangnya edukasi dan pemahaman masyarakat terkait daur ulang sampah. Daur ulang sampah organikyang paling mudah dilakukan skala rumah tangga adalah pembuatan komposter. Diambil dari data Kementerian Lingkungan Hidup dan Kehutanan pada tahun 2020 terdapat 33 juta ton sampah per tahun. Data menunjukkan 37,4\% dari sampah tersebut dihasilkan dari sampah rumah tangga. Dari jumlah tersebut sebanyak 37,61\% atau 12,57 juta ton/tahun tidak terkelola dengan benar. Pembuatan komposter ada 2 macam yaitu komposter aerob dan anaerob. Komposter aerob adalah pembuatan komposter yang membutuhkan oksigen dalam prosesnya. Komposter anaerob adalah pembuatan komposter yang kedap udara atau tidak membutuhkan oksigen.
\end{abstract}

Kata Kunci: TTG; pengelolaan sampah; pendapatan

\section{PENDAHULUAN}

Nilai jual adalah kemampuan suatu industri untuk mengolah komoditi menjadi nilai tukar yang lebih tinggi (Faizin, 2017). Nilai jual juga bisa diartikan pertambahan nilai suatu komoditas yang mengalami pengelolaan dalam suatu produksi. Dalam pengelolaan dibutuhkan sumber daya yang efektif untuk mencapai hasil tertentu. Oleh karena itu, dibutuhkan adanya manajemen pengelolaan. Pengelolaan sampah di Indonesia masih sangat terbatas. Pengelolaan sampah merupakan suatu tindakan penanganan sampah (Municipal Waste Management-MWM) mulai dari penimbunan, penyimpanan setempat, pengangkutan, pemerosesan sampai pembuangan akhir, dengan menggunakan prinsip kesehatan masyarakat, ekonomi, teknik keindahan perlindungan alam (Restuningdiah et al., 2021).

Sampah adalah sesuatu hasil sisa kegiatan manusia baik berupa kegiatan industri maupun domestic (Marliani, 2014). Sampah merupakan problematika masyarakat Indonesia sejak lama. Sampah menumpuk dan berserakan menjadi hal biasa. Bahkan sampai mencemari lingkungan yang ada disekitarnya (Yunik'ati et al., 2019). Jenis sampah menurut sifatnya ada 2. Sampah yang tidak membusuk dan sulit diuraikan yaitu sampah anorganik. Sampah anorganik adalah sampah hasil dari proses mesin dan industri. Contoh dari Sampah anorganik adalah plastik, kaleng, dan botol. Jenis sampah selanjutnya adalah sampah organik. Sampah organik merupakan jenis sampah yang paling banyak dihasilkan oleh 
manusia. Sampah organik merupakan sampah hasil sisa makhluk hidup dan dapat terurai alami dengan bantuan bakteri tanpa unsur kimia. Contoh sampah organik adalah daundaunan, kotoran hewan dan sampah rumah tangga (Environment Indonesia Center, 2020).

Banyak sampah rumah tangga yang menumpuk dan menyebabkan beberapa polusi dan penyakit akibat proses pembusukan. Sampah dianggap hal yang kotor dan tidak memiliki nilai karena merupakan hasil sisa kegiatan manusia (Axmalia \& Mulasari, 2020). Pengelolaan sampah di Indonesia kurang maksimal karena kurangnya edukasi dan pemahaman masyarakat terkait daur ulang sampah (Sholihah et al., 2019). Diambil dari data Kementerian Lingkungan Hidup dan Kehutanan pada tahun 2020 terdapat 33 juta ton sampah per tahun. Dan 37,4\% dari sampah tersebut dihasilkan dari sampah rumah tangga. Dari jumlah tersebut sebanyak $37,61 \%$ atau 12,57 juta ton/tahun tidak terkelola dengan benar.

Daur ulang sampah organik yang paling mudah dilakukan skala rumah tangga adalah pembuatan komposter. Menurut Firmansyah (2010) komposter adalah proses yang dihasilkan dari pelapukan (dekomposisi) sisa-sisa bahan organik secara biologi yang terkontrol menjadi bagian-bagian yang terhumuskan. Dalam pembuatan komposter dibutuhkan bantuan dari bakteri dan mikroorganisme lainnya. Maka dari itu, saat pembuatan komposter dibutuhkan MOL atau Mikroorganisme Lokal. Proses pembuatan MOL dapat dibuat sendiri dengan bahan EM4 dan tetes tebu yang dicampur dengan air.

Di Desa Sumbersekar tepatnya Dusun Semanding, Kecamatan Dau, Kabupaten Malang, pengelolaan sampah baik organik dan anorganik masih sangat kurang dipahami dan dilaksanakan oleh masyarakat. Kurangnya edukasi dan pemahaman masyarakat terkait daur ulang sampah organik yang bisa difungsikan sebagai sesuatu yang bisa menghasilkan. Salah satunya yaitu komposter. Pembuatan komposter ada 2 macam yaitu komposter aerob dan anaerob. Komposter aerob adalah pembuatan komposter yang membutuhkan oksigen dalam prosesnya. Komposter anaerob adalah pembuatan komposter yang kedap udara atau tidak membutuhkan oksigen. Sebelumnya di Desa Sumbersekar sudah pernah ada sosialisasi tentang komposter aerob tetapi karena kurangnya sosialisasi, masyarakat kurang berminat untuk membuat komposter tersebut. Selain itu, proses pembuatan sedikit menghasilkan bau kurang sedap dan alasan itu juga yang menyebabkan masyarakat desa kurang berminat.

\section{METODE}

Pelaksanaan kegiatan Sosialiasasi dan edukasi teknologi tepat guna komposter dilaksanakan pada tanggal 15 Agustus 2021, bertempat di Dusun Semanding, Desa Sumbersekar, Dau, Malang pada pukul 16.00 - 17.30 WIB dengan peserta sosialisasi adalah ibu-ibu PKK. Alat yang digunakan untuk pembuatan komposter adalah ember bekas yang ada tutupnya, saringan yang berdiamer lebih kurang 35-40 cm, penyangga, solder, gergaji dan selang kecil. Sedangkan bahan yang dibutuhkan adalah EM4, tetes tebu dan air cucian beras (optional jika tidak ada bisa diganti air mineral biasa). Sosialisasi kali ini menggunakan metode komposter anaerob yang berarti tidak memerlukan oksigen dalam proses penguraiannya.

\section{HASIL DAN PEMBAHASAN}

Pengolahan sampah organik paling mudah di skala rumah tangga adalah pembuatan komposter. Pengomposan merupakan proses dekomposisi terkendali secara biologis terhadap sampah padat organik dalam kondisi aerobik (terdapat oksigen) atau anaerobik (tanpa oksigen). Bahan organik akan diubah hingga menyerupai tanah. Kondisi terkendali tersebut mencakup rasio karbon dan nitrogen, kelembapan, $\mathrm{pH}$ dan kebutuhan oksigen (Ekawandani \& Kusuma, 2018). 
Proses perakitan tempat dan juga pembuatan komposter dapat dilakukan dengan bahan-bahan bekas yang sudah tidak terpakai. Contohnya seperti ember bekas cat $25 \mathrm{~kg}$ yang dapat digunakan sebagai wadah komposter. Kayu bekas dan ventilasi yang sudah tidak terpakai dapat digunakan sebagai saringan dan penyangga. Serta selang kecil atau kran yang bisa difungsikan sebagai saluran air lindi hasil komposter cair.

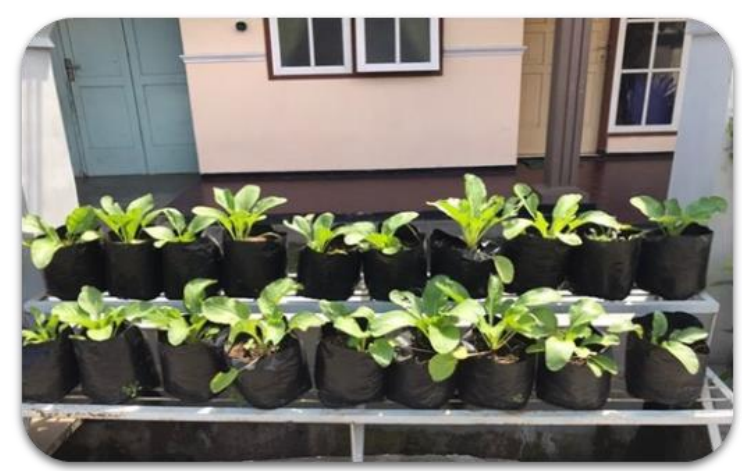

Gambar 1. Tanaman Hidroponik yang ditanam di depan rumah warga

Di Desa Sumbersekar, tepatnya Dusun Semanding banyak warga yang menanam sawi di polibek di depan rumah-rumah. Terdapat juga taman florist yang digunakan untuk menjual dan menanam tanaman hias. Dari situasi tersebut, kelompok KSM 23 memiliki ide untuk membantu membuat pupuk organik dari sampah-sampah rumah tangga. Selain untuk mengurangi sampah organik di Dusun Semanding, juga memberdayakan masyarakat untuk memproses sampah menjadi kompos yang memiliki nilai jual.

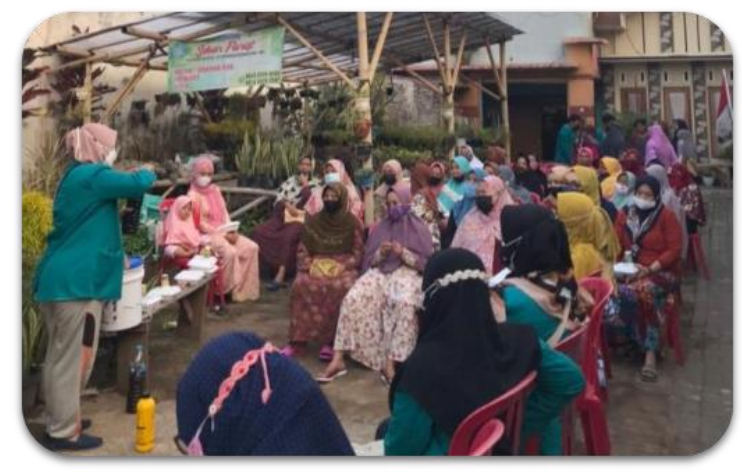

Gambar 2. Sosialisasi pembuatan komposter bersama ibu-ibu PKK

Sosialisasi pembuatan komposter anorganik dan edukasi di Dusun Semanding didasari oleh tanaman polibek serta florist yang ditangani oleh ibu-ibu PKK memiliki banyak sekali hasil sampah organik berupa daun yang layu, hama rumput, dan tangkai bunga sisa potongan yang menumpuk dan langsung dibuang tanpa diolah terlebih dahulu dan biasanya langsung dibakar. Proses perawatan florist serta polibek hanya menggunakan air kadang diberi pupuk kimia yang kurang ramah lingkungan. Oleh karena itu, pembuatan komposter selain mendaur ulang sampah, mengedukasi masyarakat, juga hasil kompos bisa dijual yang dapat meningkatkan perekonomian masyarakat di Dusun semanding.

\section{KESIMPULAN}

Kegiatan KSM yang telah kami lakukan, dapat disimpulkan bahwa warga Dusun Semanding RT 01 RW 04 perlu di edukasi lebih dalam tentang pembuatan serta proses pengomposan dari sampah organik yang ada disekitar. Dengan kegiatan ini diharapkan 
Dusun Semanding dapat mengolah sampah organik serta meningkatkan nilai jual sampah menjadi pupuk kompos organik yang ramah lingkungan.

\section{DAFTAR RUJUKAN}

Axmalia, A., \& Mulasari, S. A. (2020). Dampak Tempat Pembuangan Akhir Sampah (TPA) Terhadap Gangguan Kesehatan Masyarakat. Jurnal Kesehatan Komunitas, 6(2), 171176. https://doi.org/10.25311/keskom.vol6.iss2.536

Ekawandani, N., \& Kusuma, A. A. (2018). Pengomposan sampah organik (kubis dan kulit pisang) dengan menggunakan em4. Jurnal TEDC, 12(1), 38-43. https://ejournal.poltektedc.ac.id/index.php/tedc/article/view/129

Environment Indonesia Center. (2020). 4 Jenis Limbah Berdasarkan Wujudnya. IEC.com. https://environment-indonesia.com/articles/4-jenis-limbah-berdasarkan-wujudnya/

Faizin, I. (2017). Strategi Pemasaran Jasa Pendidikan Dalam meningkatkan Nilai Jual $\begin{array}{llll}\text { Madrasah. Jurnal } & \text { Madaniyah, 261-283. }\end{array}$ https://journal.stitpemalang.ac.id/index.php/madaniyah/article/view/75

Firmansyah, A. (2010). Teknik Pembuatan Kompos (pp. 1-19). http://kalteng.litbang.pertanian.go.id/ind/images/data/teknik-kompos.pdf

Marliani, N. (2014). Pemanfaatan Limbah Rumah Tangga (Sampah Anorganik) sebagai Bentuk Implementasi dari Pendidikan Lingkungan Hidup. Formatif: Jurnal Ilmiah Pendidikan MIPA, 4(2), 124-132. https://doi.org/10.30998/formatif.v4i2.146

Restuningdiah, N., Nagari, P. M., Jati, F. D., \& Azzardina, A. (2021). Literasi bank sampah dan asuransi sampah sebagai upaya peningkatan kesejahteraan masyarakat. Jurnal Inovasi Hasil Pengabdian Masyarakat (JIPEMAS), 4(1), 144-152. https://doi.org/10.33474/jipemas.v4i1.9140

Sholihah, F. A., Normaladewi, A., \& Laksono, P. T. (2019). Pengolahan Plastik Bekas Menjadi Bantal Hias Di Desa Ngempit Kecamatan Kraton Kabupaten Pasuruan. Jurnal Inovasi Hasil Pengabdian Masyarakat (JIPEMAS), 2(1), 9-17. https://doi.org/10.33474/jipemas.v2i1.1640

Yunik'ati, Imam, R. M., Hariyadi, F., \& Choirotin, I. (2019). Sadar Pilah Sampah Dengan Konsep 4R (Reduce, Reuse, Recycle, Replace) Di Desa Gedongarum, Kanor, Bojonegoro. Jurnal Inovasi Hasil Pengabdian Masyarakat (JIPEMAS), 2(2), 81-87. https://doi.org/10.33474/jipemas.v2i2.1122 